\title{
TEACHING STYLES AND LANGUAGE ANXIETY: THE MEDIATING EFFECT OF LANGUAGE LEARNING BELIEFS
}

\author{
Norelyn A. Fuentes ${ }^{1}$, Marilou Y. Limpot ${ }^{2}$ \\ ${ }^{1}$ Master of Arts in Filipino, University of Mindanao, Davao City, Philippines \\ ${ }^{2}$ Doctor of Education, Professor, University of Mindanao, Davao City, Philippines
}

Article DOI: https://doi.org/10.36713/epra9607

DOI No: 10.36713/epra9607

\begin{abstract}
The goal of this study was to see if language learning beliefs had a mediation influence on students' language anxiety in relation to teaching style. In this case, a descriptive correlational survey was used as part of a quantitative research project. It was conducted with 332 research participants at a private institution in Digos City. Adapted questionnaires from Grasha's Teaching Styles Inventory (2002), Horwitz's (1987) Beliefs About Language Learning Inventory (BALLI), and Foreign Language Classroom Anxiety were the three instruments used in this study. Horwitz, Horwitz, and Cope are the three levels of the FLCAS scale (1986). The Google survey form was utilized to facilitate the investigation. In the data analysis, the mean, regression analysis, Pearson $r$, and the Sobel z-test were used. As a result of this research, it has been determined that there is a very high level in each teaching style. Moderate level of anxiety in the Filipino language and high level of belief in language learning. In addition, the variables in this study show a significant correlation. Thus, as a result of the significant correlation of each variable, it was found that there was a full mediation of the effect on language learning beliefs in the correlation of teaching styles and students' language anxiety.
\end{abstract}

KEYWORDS: Digos City, belief in language learning, anxiety in the Filipino language, teaching style, mediating effect

\section{INTRODUCTION}

Learning the Filipino language, like learning any other language, is not easy. There appears to be apprehension about learning a new language. The sense of restlessness, stress, anxiety and pity that comes with learning or utilizing a second or foreign language is known as language anxiety (Horwitz 156). According to $\mathrm{Wu}$ (177), teachers should encourage students to rely on themselves rather than on the teachers. Inquisitiveness should be driven by the students themselves. Motivation and behavior are linked to language learning, according to research, It has been suggested that having a learning belief will help language learning, whereas having a different set of beliefs may hinder language learning. Language learners with a positive attitude toward the target language and realistic views are believed to have a better probability of succeeding as language learners than those with negative attitudes, behavior, and beliefs toward the target language (AlMalki, Abdullah, and Javid 190). The next issue facing the Filipino language, according to De Juan (9) is students' loss of interest in reading Filipino literary works, their attraction to a foreign culture or colonial ideas, and the difficulties in teaching important or profound terms. According to the statements of two students from the UM Digos Senior High School's grade 11 STEM strand and grade 12 HUMSS strand, they have trouble learning the Filipino language due to the norms and meaning provided by the language teacher. Because the Philippines is a multilingual country, the researchers, who are also Filipino language teachers, thought that conducting this research would shed light on the mediating effect of language learning beliefs on the relationship between teaching style and language anxiety in Senior High School students. Filipino was formally taught in all academic institutions in the Philippines as an official language. As a result, learning Filipino was like learning a new language. 


\section{OBJECTIVES}

This study aims to reveal the mediating effect of language learning beliefs on the relationship between teaching styles and language anxiety of senior high school students.

\section{METHODS}

The correlation technique was utilized in this study's quantitative non-experimental research design. This research was carried out in Digos City, Davao del Sur, at a private university. The data collection method has become more strict as a result of the pandemic's threat. In doing the study, the researcher considered her own self-interest. Furthermore, the number of students participating in this assessment is equal to the minimum number of research participants. Slovin's Formula, a Simple Random Sampling Technique, was employed by the researchers to determine the number of responders who would respond to each strand. The researchers obtained 332 responses from students with Filipino subjects. According to Köseolu (p.43), the number of participants in the study for mediation research is already sufficient at 202. Google online survey form was employed to speed up the study's completion. The researchers used three questionnaires to assess the impact of teachers' employment of various teaching approaches in the Filipino topic on students' anxiety levels and their belief in language learning. The first part includes five indicators that describe the various teaching methods of Filipino subject teachers. The questionnaire for the study was developed from Grasha's Teaching Styles Inventory (2002). Meanwhile, the second part of the questionnaire focused on the study of language anxiety, which was adapted from Horwitz, Hor-witz, and Cope's Foreign Language Classroom Anxiety Scale FLCAS study questionnaire (1986). The third questionnaire, based on Horwitz's Beliefs About Language Learning Inventory (BALLI), asks students in the Filipino subject about their language learning beliefs.

The statistics employed in this investigation were as follows in order to produce precise and reliable results. The 0.05 significance threshold was used for all interpretations. The level of anxiety in Filipino language teaching style and language learning beliefs was determined using the mean. The substantial association between Filipino language anxiety and teaching style, teaching style and language learning belief, and language learning belief and language anxiety was discovered using Pearson's $r$. The researchers employed regression to figure out which domain of anxiety in the Filipino language influenced the students' teaching style and beliefs regarding language learning.

Meanwhile, the Sobel z test was utilized in this study's mediation analysis to further identify the effect of each variable. Sobel (290) proposed the Sobel z test, which can be used to see if the relationship between the independent bar-symbol (X) and the non-independent variable $(\mathrm{Y})$ is mediated/affected by the third. If $\mathrm{X}$ and $\mathrm{Y}$ have an indirect link, the variable $(\mathrm{Y})$ is used. In a nutshell, the Sobel test determines if including the mediator (M) in the regression analysis reduces the effect of the independent variable $(\mathrm{X})$ on the non-independent variable $(\mathrm{Y})$ (Preacher p. 25).

\section{RESULTS AND DISCUSSION}

Table 1 displays the statistical findings at the level of each Filipino teaching style. The study's outcome was intriguing. Rich's research (82), which found that primary teaching style knowledge, standardized personality, and formal authority were the most desired teaching styles, was similar. According to researchers, distinct teaching styles allow them to use different teaching styles depending on the teacher's preference or learning style (Grasha \& Yangarber-Hicks 3; Harrelson et al. al. 37). As a result, various roles, attitudes, and behaviors emerge when a person employs a certain teaching method (Grasha 180). Specific teaching methods have been discovered to aid in the construction and promotion of a successful learning environment (Quitadamo and Brown 8). As a result, it is proof that when a teacher's teaching style is high, he or she captures more students' attention and so lowers students' anxiety in language acquisition.

Table 1

Level of Teaching Styles

\begin{tabular}{lccc}
\hline \multicolumn{1}{c}{ Indicators } & Mean & SD & Descriptive level \\
\hline Expert & 4.24 & .442 & Very high \\
Formal authority & 4.20 & .455 & Very high \\
Personal model & 4.23 & .469 & Very high \\
Facilitator & 4.23 & .483 & Very high \\
Delegator & 4.10 & .499 & high \\
\hline
\end{tabular}

Note: Each teaching style is recognized as unique so no total mean score is calculated.

The statistical results of the language anxiety level study are shown in Table 2. It had a moderate overall mean $(\mathrm{x}=$ $3.21, \mathrm{SD}=0.367)$. Students were reported to be at ease and confident when speaking in a study conducted by Javid (190). They speak another language in front of their classmates and are even surrounded by native speakers of another language. The 
only time they have to communicate in the target language without prior preparation is when they have to do so. Participants also stated that they did not have a lot of fear in the classroom and that they were open to taking more language programs. In contrast to Qaddomi's (1552) study, it was discovered in his study that EFL learners from QOU experienced fear, particularly when communicating with native speakers.
According to Al Asmari (59), teachers should utilize appropriate strategies such as group or pair work in order to perform the target language more often and avoid negative anxiety while forecasting. According to the findings of Zhaniresearch, bek's when students are apprehensive about themselves, they are less engaged in participating in classroom activities.

Table 2

Level of Language Anxiety

\begin{tabular}{|c|c|c|c|}
\hline Indicators & Mean & SD & Descriptive level \\
\hline communication apprehension anxiety & 3.04 & .378 & moderate \\
\hline test anxiety & 3.10 & .423 & moderate \\
\hline negative evaluation & 3.65 & .560 & high \\
\hline anxiety of Filipino classroom & 3.07 & .379 & moderate \\
\hline Overall & 3.21 & .367 & moderate \\
\hline
\end{tabular}

The five indicators are high-level, indicating that students frequently notice the impact of their language learning beliefs. The statistical results of the examination for the level of belief in language acquisition are shown in Table 3. A total mean score of $(\mathrm{x}=3.85, \mathrm{SD}=0.421)$ was obtained, indicating a high level of achievement. Because a growing body of research shows that motivation and language acquisition is closely proportional to each other (Al-asmari and Javid 79; Dörnyei 6), this is a very positive indicator of learners' performance in foreign language learners. The highest item in this category is the notion that if they want to speak the target language, they have many opportunities to use it. This is a very positive sign that learners have this confidence and intention to take advantage of the wide range of online resources they can use to learn and get used to the target language and help them become self-sufficient and lifelong. learns. The findings also reveal that students have a strong instrumental drive to achieve the desired level of second language proficiency, as seen by the very high mean value assigned by some studies conducted in the Arab world as well as non-Arab contexts in the EFL (Javid \& AlMalki 40; Al-Asmari \& Javid 80; Fujiwara 89; Bernat and Lioyd 5).

Table 3

Level of Language Learning Beliefs

\begin{tabular}{lccc}
\hline \multicolumn{1}{c}{ Indicator } & Mean & SD & Descriptive level \\
\hline Foreign Language Aptitude & 3.79 & .501 & high \\
Difficulty of language learning & 3.61 & .416 & high \\
The nature of language learning & 3.92 & .507 & high \\
Learning and communication strategies & 3.90 & .479 & high \\
Motivations and expectations & 4.02 & .543 & high \\
$\quad$ Overall & 3.85 & .421 & high \\
\hline
\end{tabular}

Based on the results of the study, students 'language anxiety had a significant correlation with teachers' teaching styles. Supported from the results of the study of Mohammadi et.al. (643) that each level of anxiety in language learning is correlated with the level of teaching style. Instructional strategies contribute to the development of the language system in which students form and are directly affected by learning. It can be concluded that the knowledge and use of language learning strategies can be improved and enhanced in language learning. If teachers adopt the right teaching strategies to the needs of their students, it will improve their learning and their level of language anxiety Mohammadi et.al. (644). According to the study of Noohormohamadi (50), a student's anxiety is affected by external variables including teaching and testing skills, peer interaction, general task requirements, and the teaching environment. Kaya's study (45) also shows that there is a relationship between anxiety, motivation, self-confidence, extroversion/introversion, and participation in foreign language classes.

Teachers 'teaching style has a significant correlation with students' language learning beliefs. This is supported by the research of Al-malki \& Javid 193 that each level of teaching 
style is related to the belief of language learning. The findings of this study show that it seems an international opinion that it is better to expose students to the target language from childhood to expand their ability to learn a second language. Differences can be found in their perspectives towards the belief that there are people born with special abilities for foreign language learning (Javid \& Al-Malki 192; Al-Roomy 22; Fujiwara 102.)

Lastly, belief in language learning and language anxiety also showed a significant correlation thus rejecting Ho who stated that there was no significant correlation between belief in language learning and language anxiety. This was supported by the study by Azher et al. (37) that typically, high anxiety can weaken students, lose confidence in their abilities, escape from participating in classroom activities, and give up trying to learn a language when good. Therefore, students with high anxiety often get the low achievement and low learning achievement makes learning more anxious. Their belief in learning decreases. On the other hand, in the study by Aslan, Erhan, and Amy S. Thompson (189) that positive beliefs about language learning can help reduce anxiety and boost confidence in learning the language. Tuncer, Murat, and Yunus Doga (17) added that in order to facilitate the language learning process of students, the effect of anxiety should be reduced

Table 4

Correlation matrix of the variables

\begin{tabular}{clccc}
\hline Pair & \multicolumn{1}{c}{ Variables } & $\begin{array}{c}\text { Correlation } \\
\text { Coefficient }\end{array}$ & $\boldsymbol{p}$-value & $\begin{array}{c}\text { Decision of } \\
\text { HO }\end{array}$ \\
\hline IV at DV & Teaching Styles and Language Anxiety & 0.227 & $<0.000$ & Reject \\
IV at MV & $\begin{array}{l}\text { Teaching styles and Language Learning } \\
\text { Beliefs }\end{array}$ & 0.620 & $<0.000$ & Reject \\
MV at DV & $\begin{array}{l}\text { Language Learning Beliefs and Language } \\
\text { Anxiety }\end{array}$ & 0.358 & $<0.000$ & Reject \\
\hline
\end{tabular}

Table 5

Regression analysis showing the influence of each important teaching style on anxiety in the Filipino language after being mediated by belief in language learning

\begin{tabular}{lcccc}
\hline Step & Path & Beta (Unstandardized) & Standard Error & Beta (Standardized) \\
\hline Step 1 & c & 0.188 & 0.039 & $0.227^{* *}$ \\
Step 2 & a & 0.588 & 0.036 & $0.620^{* *}$ \\
Step 3 & b & 0.305 & 0.050 & $0.351^{* *}$ \\
Step 4 & c' & 0.009 & 0.048 & $0.010^{\text {ns }}$ \\
\hline
\end{tabular}




\section{Medgraph}

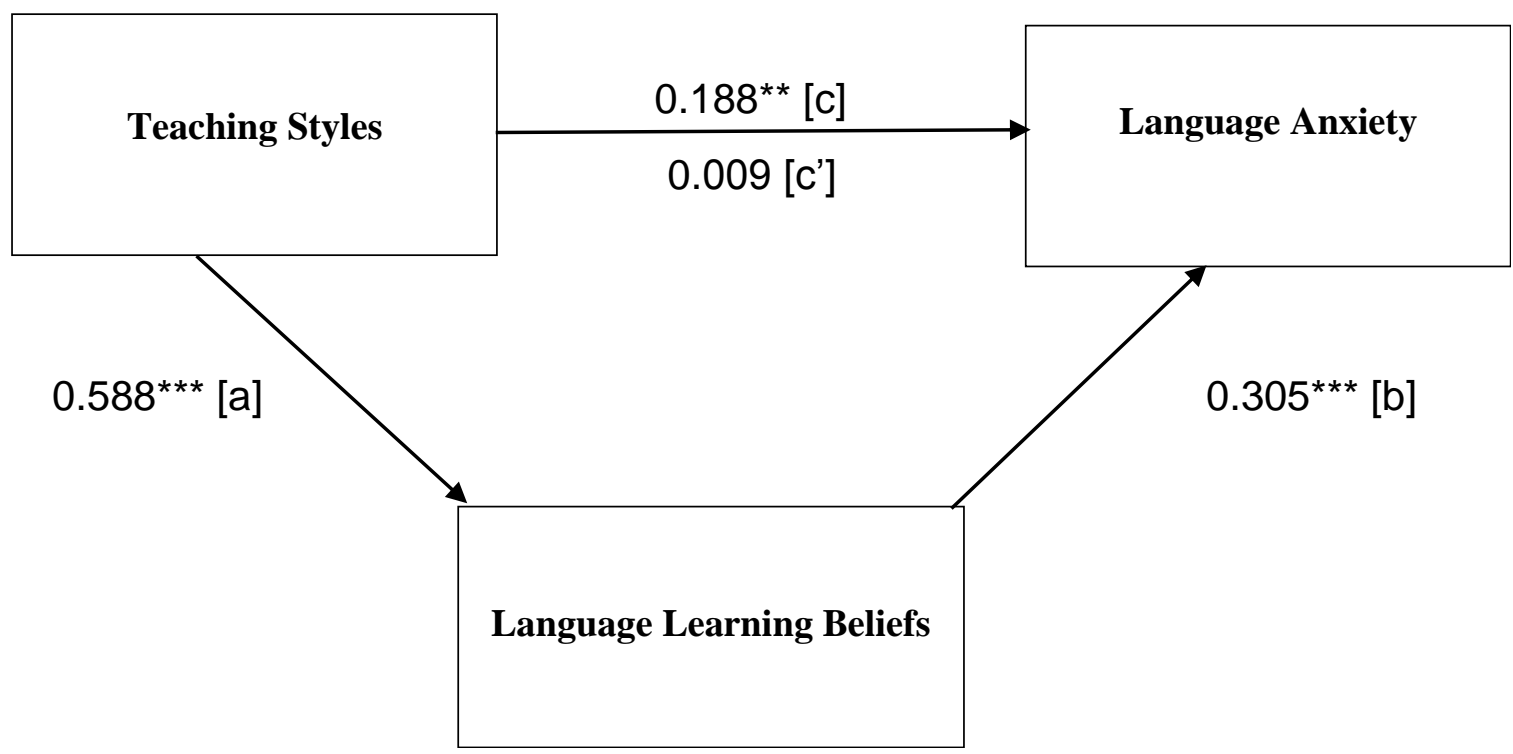

The first step path (c) showed a significant effect from variable teaching style towards anxiety in the Fil-refined language with $(\mathrm{B}=0.188, \mathrm{SEB}=0.039)$. Then, the next step announced in the path (a), showed a direct effect of variable teaching style with still indicative expertise and variable belief in language learning gaining $(\mathrm{B}=0.588, \mathrm{SEB}=0.036)$ which means that there is a significant correlation between the range of variables. A third step performed on the regression of the variables presented in the path (b), exposed the direct effect of the mediator variable belief on language learning on language anxiety that obtained $(\mathrm{B}=0.305, \mathrm{SEB}=0.050)$ stated of significant correlation between variables. Of the three steps performed that revealed a significant correlation of each variable, the final step performed was the path (c ') using multiple regression that showed a direct effect of teaching style with still indicator of expertise and language anxiety using the mediator variable belief in language learning showing $(\mathrm{B}=$ $0.009, \mathrm{SEB}=0.048)$, which resulted in no significant correlation needed for this to be the basis of the existence of full mediation.

Table 6

Results of a statistical analysis aimed at detecting the presence (or absence) of a mediation/mediating effect

\begin{tabular}{lccccc}
\hline & Combination & Sobel z & $p$-value & Mediation \\
\hline $\begin{array}{l}\text { Teaching } \\
\text { anxiety }\end{array}$ & styles $\rightarrow$ language learning beliefs $\rightarrow$ language & 5.706526 & $<0.000$ & Full \\
\hline
\end{tabular}

Table 6 shows the results of the study that show the mediating effect of belief in language learning on the relationship between teaching style and anxiety in the Filipino language of students. Based on the collected data, it was found that there is a full mediation or mediating effect on teaching style between the relationship of belief in learning to student anxiety in learning Filipino.

\section{CONCLUSION}

In this study, the researcher realized that the three variables have a significant relationship with each other. The teaching style and language anxiety, teaching style and language learning beliefs, and language learning beliefs and language anxiety. The result in the correlational coefficients shows a positive and strong relationship. It only proves as an implication that when language teaching is improved using different teaching styles by teachers it strengthens students' language learning beliefs which is a reason to alleviate their anxiety in 
learning the language. It is therefore suggested that teachers and students attend seminars or conferences about their responsibility within the classroom and their contribution to the class, especially in language learning to further increase their knowledge and success in teaching. Linguists and other researchers can also conduct comparative research based on ethnographic profiles such as gender, ethnic group, and learning style. Since the data were only obtained in private schools that there is an online learning method of teaching in the new normal of education due to COVID-19 that limits the learning environment. It is suggested to do a similar study that can be done in another area focused on the public school so that the result can be compared. Other factors may also be used that were not used in this study.

\section{REFERENCES}

1. Al Asmari, AbdulRahman. "A Comparative Analysis of Preparatory Year Students' FL Anxiety." International Journal of English Linguistics 5.4 (2015): 50.

2. Al-Malki, Eidah Abdullah, and Choudhary Zahid Javid. "Identification of Language Learning Beliefs among Saudi EFL Learners." Arab World English Journal (AWEJ) Volume 9 (2018).

3. Al-Malki, Eidah Abdullah, and Choudhary Zahid Javid. "Identification of Language Learning Beliefs among Saudi EFL Learners." Arab World English Journal (AWEJ) Volume 9 (2018) Al-Roomy, Muhammad. "Evaluating Saudi university students' beliefs about learning English." International Journal of English Linguistics 5.1 (2015): 22.

4. Aslan, Erhan, and Amy S. Thompson. "The interplay between learner beliefs and foreign language anxiety: insights from the Turkish EFL context." The Language Learning Journal 49.2 (2021): 189-202.

5. Asmari, A. A., and C. Z. Javid. "Motivational Constructs: A Cross Sectional Study EFL Students at Taif University." Journal of Social Sciences \& Humanities 19.2 (2011): 73-104.

6. Azher, Musarrat, Muhammad Nadeem Anwar, and Anjum Naz. "An investigation of foreign language classroom anxiety and its relationship with students achievement." Journal of College Teaching \& Learning (TLC) 7.11 (2010).

7. Bernat, Eva, and Inna Gvozdenko. "Beliefs about Language Learning: Current Knowledge, Pedagogical Implications, and New Research Directions." Tesl-ej 9.1 (2005): $n 1$.

8. De Juan, (2013). Mga Suliranin ng mga Guro sa Pagtuturo ng Filipino. R etrieved from https://filipinotek.wordpress.com/2013/03/29/.com

9. Dörnyei, Zoltán. The psychology of the language learner: Individual differences in second language acquisition. Routledge, 2014.

10. Fujiwara, Takayoshi. "Language Learning Beliefs of Thai EFL University Students: Variations Related to Achievement Levels and Subject Majors." Electronic Journal of Foreign Language Teaching 11.2 (2014).
11. Grasha, Anthony F. "A matter of style: The teacher as expert, formal authority, personal model, facilitator, and delegator." College teaching 42.4 (1994): 142-149.

12. Grasha, Anthony F., and Natalia Yangarber-Hicks. "Integrating teaching styles and learning styles with instructional technology." College teaching 48.1 (2000): 2 10.

13. Horwitz, Elaine $K$. "Foreign and second language anxiety." Language teaching 43.2 (2010): 154-167.

14. Javid, Choudhary Zahid. "Measuring language anxiety in an EFL context." Journal of Education and Practice 5.25 (2014): 180-193.

15. Kaya, Meral. The relationship of motivation, anxiety, selfconfidence, and extroversion/introversion to students' active class participation in an EFL classroom in Turkey. Diss. Bilkent University, 1995.

16. Köseoğlu, Y. "To What Extent Can the Big Five and Learning Styles Predict Academic Achievement." Journal of Education and Practice, vol. 7, no. 30, 2016.

17. Mohammadi, Ebrahim Ghorban, et al. "The relationship between foreign language anxiety and language learning strategies among university students." Theory and practice in Language Studies 3.4 (2013): 637.

18. Noormohamadi, Rezvan. "On the Relationship Between Language Learning Strategies and Foreign Language Anxiety." Journal of Pan-Pacific Association of Applied Linguistics 13.1 (2009): 39-52.

19. Preacher, et al. "Calculation for the Sobel Test: An Interactive Calculation Tool for Mediation Tests.",2020p.20-24 Retrieved August 27, 2020 from http://quantpsy.org/sobel/sobel.htm

20. Qaddomi, Hussam. "Investigating Al-Quds Open University Students' EFL Learning Anxiety." (2013).

21. Quitadamo, Ian J., and Abbie Brown. "Effective Teaching Styles and Instructional Design for Online Learning Environments." (2001).

22. Rich, Valerie J. "Educational backgrounds and teaching styles of athletic training educators in entry-level CAAHEP accredited athletic training programs." (2006).

23. Sobel, M. E. Asymptotic Intervals for Indirect Effects in Structural Equations Models. Edited by S. Leinhart, JosseyBass, 1982, pp. 290-312.

24. Tuncer, Murat, and Yunus Dogan. "Effect of Foreign Language Classroom Anxiety on Turkish University Students' Academic Achievement in Foreign Language Learning." Journal of Education and Training Studies 3.6 (2015): 14-19.

25. Wu, Ya-Ling. "Language learning strategies used by students at different proficiency levels." Asian EFL Journal 10.4 (2008): 75-95.

26. Zhanibek, Ardak. The relationship between language anxiety and students' participation in foreign language classes. Diss. Bilkent University, 2 